\title{
Demons and Tutelary Deities from Heaven
}

\author{
The Hyleme-Pattern “X Descends from Heaven” in Akkadian \\ Incantation Literature
}

\begin{abstract}
This paper is concerned with the phenomenon of heaven-sent entities in Mesopotamian magical texts. The heavenly travellers can be malevolent (demons bringing diseases) as well as benevolent (tutelary deities coming to the aid of ailing humans), and their descent from heaven to earth can take place in a variety of ways, and with the aid of various implements such as a rope, by being transformed into falling stars, or simply falling down to earth by accident.
\end{abstract}

\section{Introduction}

When studying the Mesopotamian incantation corpora, one notices multiple differences between the Sumerian and Akkadian traditions. One of the innovations of the Akkadian incantation corpora is the use of the hyleme-pattern " $\mathrm{X}\left({ }_{1-2}\right)$ descends from heaven". ${ }^{1}$ This hyleme-pattern is incorporated in the hylemesequence of mythical introductions (historiolae) in incantations describing the origins of mostly malevolent entities, such as diseases and demons descending from heaven to earth. Although aspects of this feature within Akkadian incantations have been recognized and briefly discussed by various scholars (Farber 1990; Stol 1993, 12-14; Cunningham 1997, 177; Wasserman 2007, 40-61), a systematic overview has never been presented. This study seeks to provide a novel approach to investigating " $\mathrm{X}\left({ }_{1-2}\right)$ descends from heaven" as a hyleme-pattern within Akkadian incantations by deploying the innovative method devised by Christian Zgoll (2019).

Note: This paper is the result of a collaboration with the Collegium Mythologicum in Göttingen. I would like to express my sincere gratitude to Annette and Christian Zgoll for inviting me to participate in this innovative approach to the investigation of ancient texts. Furthermore, I am thankful for the rich and fruitful discussions with all members of the Collegium Mythologicum.

1 For the terminology (hyleme, hyleme-pattern etc.) see C. Zgoll, Grundlagen der hylistischen Mythosforschung, in this volume; for an earlier version in English see C. Zgoll 2020. 


\section{2 " $X_{1}(=$ Malevolent) Descends from Heaven"}

\subsection{Origins of Malevolent Entities in the Sumerian Incantation Literature}

From the perspective of the Sumerian incantation tradition, the entities of evil ${ }^{2}$ are described to be present (i.e., to mainly originate from) geographical places such as the Abzu and the Netherworld, which aligns well with the general Sumerian belief that evil spirits have their actual dwelling place in the Netherworld, see Katz (2003, $44 \mathrm{f}$ and passim). ${ }^{3}$ In the selection of examples presented below (§§ 2.1.1-2.1.5), we find unilingual Sumerian incantations from the third and second millennium BCE describing the evil occurrences that are said to have emanated from such places. A full study on hyleme-patterns occurring in Sumerian incantations, such as " $\mathrm{X}_{(1-2)}$ comes out the Abzu", describing this transfer from the Abzu and the Netherworld to earth is certainly warranted, but is beyond the scope of the present study.

\subsection{1 (Ur III) La trouvaille de Dreheme, 1 (Ist D -): 3 (spell against snakes)}

Recent edition: Conti 1997, 268 f; Rudik 2015, 282-287

piriĝg-e a-gal-a še e-ni-ib $-g i_{4} \quad$ Lion, who roars in high water

\subsection{2 (Ur III) YOS 11, 37 (MLC 1093): 2 f (spell against scorpions)}

Recent edition: Cavigneaux 1994, 157 n. 6; Rudik 2015, 372

gud-kukku ${ }_{5 .}$ g abzu pirî

Black bull from the Abzu! Lion from

$\mathrm{e}_{2}-\mathrm{kukku}_{5}$.g-ga

the dark house!

2 The phrase "entities of evil" is preferred here, since Mesopotamian incantations do not differentiate between dangerous animals, diseases, demons and evil spirits.

3 For a full discussion on the transfer, along with its related terminology, from earth to the Netherworld, see Katz 2003, 32-42. 


\subsection{3 (Ur III) PBS 1/2, 131 (CBS 8230): 4-6 (spell against snakes)}

Recent edition: Van Dijk 1969, 542; Rudik 2015, 278-281

muš lugal-zu mu-ši-gi 4

Snake, your king has sent you!

lugal-zu dnin-a-zu mu-ši-gi ${ }_{4}$

Your king Ninazu has sent you!

The fact that the snake originates from the Netherworld is clear from the fact that it has been sent by Ninazu, a deity well-connected with the Netherworld, see Wiggermann (1998-2000, 330).

\subsection{4 (OB) Udughul Forerunner (Ni 623+2320): vii 47 f (spell against Utukku- demons)}

Recent edition: Geller 1985, 34 f; Geller 2016, 135

a-ra-li-a g $\operatorname{iri}_{3}[\mathrm{mu}]^{-}{ }^{\mathrm{u}} \mathrm{un}-\mathrm{ne}^{\mathrm{l}}$-e - In the Netherworld, the path is laid gar ${ }^{\top}$ irigal-la ${ }^{1} \mathrm{kan}_{4} \mathrm{mu}^{-}{ }^{\top} \mathrm{un}^{1}$ - $\quad$ out for them (i.e., the heptad-group ne- ${ }^{-} \mathrm{e}^{\mathrm{l}}-\mathrm{g}_{\mathrm{al}} \mathrm{l}_{2}$ Sebettu), in Hades, the gate is open for them

\subsection{5 (OB) Udughul Forerunner (Ni 631): i 33 (spell against Utukku-demons)}

Recent edition: Geller 1985, 42 f; Geller 2016, 211

[idim ab]zu- ${ }^{-}$ta agrun-ta ${ }^{1}$

$e_{3} \cdot d-a-m e-e \check{s}$
They (i.e., the heptad-group Sebettu) came out of the [source] of the Abzu, from the sanctuary

This Sumerian perception survives in Akkadian incantation literature, but mainly appears in incantations that originate from the Sumerian tradition, especially the Udug.hul-series of the first millennium. ${ }^{4}$ Another interesting example is displayed in a bilingual passage of the Šurpu-series:

4 This is reflected in the examples $\S \S 2.1 .4-2.1 .5$, which are precursors to the later series. However, this input from the Sumerian tradition is continued and preserved in the later standardized series, see Geller 2016, 135.211. 


\subsection{6 (SB) Šurpu-series VII $1 \mathrm{f}$ (spell against a malevolent oath)}

Recent Edition: Reiner 1970, 36

$\mathrm{bu}\left[\mathrm{ru}_{5}\right] \check{\mathrm{s}} \mathrm{a}_{3} \cdot \mathrm{g} \mathrm{abzu}-\mathrm{ta}$

im-ta-[e $3 . d]-a-n a$

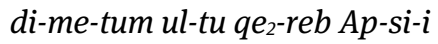

it-ta-șa-a

Sum: Locusts came out of the midst of the Abzu!

Akk: The dimētum-illness came out

of the midst of the Apsû!

Interestingly, this Sumerian imagery is occasionally continued in other genres of Akkadian literature, as is demonstrated below in the Babylonian Poem of the Righteous Sufferer (here cited after its incipit Ludlul bēl nēmeqi).

\subsection{7 (SB) Ludlul bēl nēmeqi II 51-55}

Recent Edition: Oshima 2014, 88 f

šu-uz-lu lem-nu it-ta-șa-a AB.ZU-uš-šu

The evil cough-demon went out from ' $u_{2}$-tuk'-ku la n[e $e_{2}$-' $i$ u $u_{2}-s+a-a$ ul-tu his Apsû

$e_{2}$-kur la-maš-tum u[r]-da iš-tu

$q e_{2}-r e b$ KUR-i it-ti A.ME[š] ILLU

The unstoppable Utukku-demon left from the Ekur

šu-ru-up-pu-u i-nu-šu

Lamaštu descended from the midst of the mountains

with the water of the seasonal flood, the šuruppî-disease surged (towards me)

Note that the same sequence is repeated in Ludlul bèl nèmeqi III 70-74, where all evil entities are said to have been driven back to their point of origin, see Oshima $(2014,98 \mathrm{f})$.

\subsection{Overview Attestations: " $\mathrm{X}_{1}(=$ Malevolent $)$ Descends from Heaven"}

Starting from the Old Babylonian period, we can observe a new tendency to ascribe heavenly origins to malevolent entities who had come down to earth. Whereas the unilingual Sumerian incantations simply state the origins of evil, the Akkadian incantations often extend the description by naming a specific instru- 
ment of transfer (i.e., țurru "string”, șerretu "(leading-)rope”, kakkabu "star" often described with a predicate of the verb (w)arādu "to go down, to descend"). One exception is found in example $\S 2.2 .5 .1$, where the verb maqātu "to fall down" is used. ${ }^{5}$ Whether the use of the hyleme-pattern in incantations is a pure Akkadian innovation can now be called into question by one Old Babylonian unilingual Sumerian example (§ 2.2.1.1). However, without further evidence, the thorough adaptation of the hyleme-pattern " $\mathrm{X}\left({ }_{1-2}\right)$ descends from heaven" in Akkadian incantations - starting in the second millennium and extending to the first millennium - and the meagre occurrence in the Sumerian incantations inclines one to suppose that, in case of the example $\S$ 2.2.1.1, the hyleme-pattern in question could regressively be used in Sumerian compositions.

In the following, all examples for the hyleme-pattern " $\mathrm{X}_{1}$ (=malevolent) descends from heaven" are listed after their specific instrument of transfer.

\subsection{1 " $X_{1}(=$ Malevolent $)$ Descends from Heaven" - No Specified Instrument}

\subsubsection{1 (OB) CUSAS 32, 12 (MS 3096): i 26' (spell against the Namtar-demon)}

Recent Edition: George 2016, 41

[n]am-tar sa $\hat{\mathrm{g}}$ an-ta

Namtar came down from heaven's

$e_{11} \cdot d-[d] e_{3}-d e_{3}$

heights

\subsubsection{2 (OB) AMD 14, 191 (A 663): 9 (spell against the maškadu-disease)}

Recent Edition: Collins 1999, $234 \mathrm{f}$

iš-tu ša-mi ur-da-am

From heaven, it (i.e., maškadu-

disease) descended

\subsubsection{3 (OB) Semitica 61, 13 f: $6 \mathrm{f}$ (spell against various diseases)}

Recent Edition: Guichard 2019, 8-12

5 In this respect, we should note AN.TA.ŠUB.BA/miqit šamê "that what has fallen from heaven", which is a scientific expression in Mesopotamian medical literature for epilepsy. For a full discussion and further literature on AN.TA.ŠUB.BA/miqit šamê, see Stol 1993, 7-21. It has been debated whether in $\S$ 2.2.5.1 a form of epilepsy is meant by RI.RI.GA/miqittu "collapse" due to its obscure context. An alternative translation of this incantation, affirming its allusion to a form of epilepsy, is provided in Zomer 2018, 90 n. 391. 
iš-tu ša-me-im ur- ${ }^{[} d u-n i-i m^{1}$

From heaven they (i.e., various diseas-

es) descended

\subsubsection{4 (OB) JCS 9, 9 (Spurlock 1913.14.1465): 10 (spell against various diseases)}

Recent Edition: Goetze 1955, 8-18; Collins 1999, 279-2826

iš-tu zi-qu2-ra-at ša-me-e ur-du-ni

From the ziqqurat of heaven, they (i.e., various diseases) descended

\subsubsection{5 (OB) $R A$ 88, 161 (M. 15289): r. 11' (spell against various diseases)} Recent Edition: Cavigneaux 1994, $156 \mathrm{f}$

i-na zu-quz-ra-an ša-me-e ur-da-ma

From the height of heaven, it (i.e., a group of various diseases) descended

\subsubsection{6 (MB/MA) Priests and Officials, $199 \mathrm{f}$ (Private Collection): 27 (spell against fever)}

Recent Edition: Tsukimoto 1999, 187-200; Scurlock 2014, 417-421

ina $u_{4}$-mi ina an-e ib-ba-ni ${ }^{\mathrm{T}} \mathrm{x}^{1}[\ldots i] \mathrm{s}^{-} \quad$ In the day when [...] was created in

$t[u$ an-e $u] r-d[a-a m]$ heaven, it descended from heaven

\subsubsection{7 (MB/MA) Ugaritica 5, 17 (RS 17.155): $20 \mathrm{f}$ (spell against various diseases)}

Recent edition: Rowe 2014, 48-58; Zomer 2018, 249-251

[ki K]I.MIN ib-nu-šuz-nu-ti ki $u_{2}-r a b-b i-$ šuz-nu-ti

[ki nam]-ri-re MI.IR.ME.RI ${ }^{7}-\check{s ̌ n}_{2}-n u-t i$ TA AN-[e ur-du-ni]
[When DIT]TO (i.e., the god Ea) created them; when he raised them; when he had covered them with a (terrifying) brilliance, [they (i.e.,

6 Identifiable in both publications by its former siglum UIOM 1059.

7 For later parallels of $M u s ̌ s ̌ u ' u ~ V / d$ read $u_{2}$-šal-mi-šu $u_{2}-n u-t i$ (BM 46276+) and $u_{2}$-šar-me-šuz-nu-ti (K 8487), see Böck 2007, 191-196. As for MI.IR.ME.RI-šuz-nu-ti, Dietrich 1988, 98 proposes namrirr̄ $i\left(/ u^{?}\right)$ mermerī-šunūti interpreting a preterite of $\sqrt{ } m r m r \bar{n}$, a denominative form of namrirrū (awe- 
various diseases) descended] from heaven

2.2.1.8 (SB) AMD 8/1, pl. 31 (K 8112+K 9666 (+)): i 13'-16'//TCL 6, 49

(AO 6473): 16-18//KAL 2, 36 (VAT 14151+14152+14153+): v 31'-33' (spell against witchcraft)

Recent edition: Abusch/Schwemer 2011, 159-198

it-tar-da-ni ana ma-a-ti kaš-ša-pa-a- The witches, the lying ones, have $\mathrm{tu}_{2}$ e-li-ia-na-ti i-ša $a_{2}$-as-sa-a il-lu!-ru descended to the land. They shout out i-sah-h̆a-ru za-ma-ra na-ša $a_{2}$-a me-e 'illuru!', they start to sing, they carry $a$-ab!-ba! tam-tim DAGAL-tim water from ocean, the wide sea

\subsubsection{9 (SB) LKU 32 (VAT 14505): 12 (spell against Lamaštu)}

Recent Edition: Farber 2014, 271

La-maš-ti iš-tu an-e ur-dam-ma Lamaštu descended from heaven

\subsubsection{0 (SB) KAR 165 (VAT 10072): r. 5 (spell against a malevolent oath)} Recent Edition: Reiner 1958, $4 \mathrm{f}$

ma-mit DUMU.MUNUS [Anim ittarad ištu māmìtu (the malevolent oath), $\mathrm{AN}]-e$ daughter of [Anu, has descended from heaven $]^{8}$

\subsubsection{1 (SB) CT 51, 142 (BM 38586): 11 // JCS 31, 218 f (CBS 11304): 9 (spell against Utukku-demons)}

Recent Edition: Geller 2016, 54

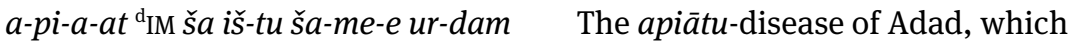
descended from heaven

inspiring radiance), with a transitive meaning; Arnaud 2007, 83 prefers a phonetic rendering of $\mathrm{GIR}_{5 / 6} . \mathrm{GIR}_{5 / 6}$ (halāpu D) "to clothe s.o. with".

8 Restoration after Reiner 1958, 4 f. 


\subsubsection{2 (SB) Šurpu-series VII 3 f (spell against a malevolent oath)}

Recent Edition: Reiner 1958, 36

nam-erim $\check{s}_{2} \mathrm{a}_{3} . \mathrm{g}$ an-na-ta māmitu (the malevolent oath) de$\mathrm{im}-\mathrm{ta}-\mathrm{e}_{11} \cdot \mathrm{d}-\mathrm{d}\left[\mathrm{e}_{3}\right]$ scended from the midst of heaven

$m a-m i-t u_{4} u l-t u q e_{2}-r e b$ AN-e ur-da

\subsubsection{3 (SB) Muššu'u-series V/d 25 (spell against various diseases)}

Recent Edition: Böck 2007, 191

TA AN-e $\mathrm{DIM}_{3}+\mathrm{AS} . \mathrm{RU}^{9} u r-d u-n i$

From heaven, the ...-demons descended

\subsection{2 " $\mathrm{X}_{1}(=$ Malevolent) Descends from Heaven"-with țurru "String"}

\subsubsection{1 (MB/MA) Ugaritica 5, 17 (RS 17.155): r. 20' (spell against fever)} Recent Edition: Tsukimoto 1999, 189 f; Arnaud 2007, 77-89; Rowe 2014, 48-58

[IZI] me-ḩu-ü IZI MURU2 iṣ-bat țur-ra TA AN-e $u r-d a$
Fire of a violent storm! Fire of battle! It (i.e., fire = fever) grasped a string, it descended from heaven

\subsubsection{2 (MB/MA) AuOr Suppl. 23, 14 (RS 94.2178): 1 (spell against fever)} Recent Edition: Arnaud 2007, 55-58; Rowe 2014, 59-61; Zomer 2018, 259 f

IZI.MEŠ me-ḩu- $u_{2}$ IZI.MEŠ $q a b_{2}{ }^{-}{ }^{\top} e l^{1}$

‘ișbat '!(IZI) țur-ra iš-tu U[GU]
Fire of a violent storm! Fire of battle! It (i.e., fire = fever) grasped a string from above

2.2.3 " $\mathrm{X}_{1}(=$ Malevolent) Descends from Heaven"-with șerretu "(Leading-)Rope"

2.2.3.1 (OB) JCS 9, 10 (HTS 2): $10 \mathrm{f}$ (spell against various diseases)

Recent Edition: Goetze 1955, 8-14; Collins 1999, 282-286

9 Böck 2007, 215. 
[iš]-tu șe $e_{2}-r e-e t[\check{s}] a-m e-e ~ u r-d u-n i$

From the (leading-)rope of heaven, they (i.e., various diseases) descended

\subsubsection{2 (SB) BAM 543 (K 2419+): iv 26' (spell against various diseases)}

Recent Edition: Farber 1990, 316-318; Collins 1999, 292-295

iš-tu șer-ret AN-e ur-du-u-[ni]

From the (leading-)rope of heaven, they (i.e., various diseases) descended

\subsubsection{3 (SB) BAM 182 (0 194): 14' (spell against the maškadu-disease)} Recent Edition: Collins 1999, $238 \mathrm{f}$

$m a s ̌-k a_{15}-d u_{3} i s ̌-t u$ șe-er-〈ret $\rangle$

ša $a_{2}-m a-m e$ ur-di
The maškadu-disease descended from the (leading-)rope of heaven

\subsection{4 " $\mathrm{X}_{1}(=$ Malevolent) Descends from Heaven"-with kakkabu "(Falling) Star"}

\subsubsection{1 (OB) YOS 11, 8 (NBC 6321): 5 (spell against various diseases)} Recent Edition: Goetze 1955, 11-18; Collins 1999, 286-288

iš-tu MUL ša-me-e ur-du-nim From a star of heaven, they (i.e., various diseases) descended

\subsubsection{2 (MB/MA) AS 16, $287 \mathrm{f}(\mathrm{Rm} 376)$ : ii 1 (spell against the maškadu- disease)}

Recent Edition: Böck 2007, 261-265.290-293.304 f.311-313; Zomer 2018, 270-272

KI MUL AN-e ${ }^{\mathrm{r}} \boldsymbol{u}_{2}{ }^{\mathrm{T}}-[\mathrm{ri}-\mathrm{da} a-a m-m a]$

With a star from heaven, it (i.e., the maškadu-disease) [descended]

\subsubsection{3 (SB) STT 136 (Su. 51/102+): iv 18 (spell against the maškadu-disease)} Recent Edition: Collins 1999, 235 f 


\subsubsection{4 (SB) OECT 6, 23 (K 3209): 5' (spell against the maškadu-disease)}

Recent Edition: Collins 1999, 253-255

iš-tu MUL.MEŠ $\check{s} a_{2}-m a-m i$ ur-da

From the stars of heaven, it (i.e., the maškadu-disease) descended

\subsubsection{5 (SB) CT 23, 2-4 (K 2473+K 2551): r. 15 // CT 23, 5-14 (K 2453+):} iii 37(spell against the maškadu-disease)

Recent Edition: Collins 1999, 236-238

$i \check{s}$-tu MUL.MEŠ ša $a_{2}-m a-m i$ ur-da

From the stars of heaven, it (i.e., the maškadu-disease) descended

2.2.4.6 (SB) STT 136 (Su 51/102+): iii 34' f // JNES 49, 300 (K 6250): 9' f (spell against various diseases)

Recent Edition: Farber 1990, 316-318; Collins 1999, 297-300

$i \check{s}-t u$ MUL(.MEŠ) ša $a_{2}-m a-m i$ ur-da ur-dam-ma iš-tu MUL(.MEš) ša $a_{2}-m a-m i$
From the star(s) of heaven it (i.e., the maškadu-disease) descended, it descended from the star(s) of heaven!

\subsection{5 " $\mathrm{X}_{1}(=$ Malevolent) Falls from Heaven"-No Specified Instrument}

\subsubsection{1 (MB/MA) Ugaritica 5, 17 (RS 17.155): r. 12' (spell against collapse)}

Recent Edition: Arnaud 2007, 79; Rowe 2014, 48-58

ina AN-e ib-ba-ni RI.RI.GA TA AN-e ina qa-qa-ri in-taq $2-t a$
In heaven collapse was created, it fell from heaven down to earth 


\section{3 " $\mathrm{X}_{2}$ (=Benevolent) Descends from Heaven"}

\subsection{Overview Attestations: “ $\mathrm{X}_{2}$ (=Benevolent) Descends from Heaven"}

The benevolent entities called the mārāt Ani $(m)$ "daughters of Anu", feature quite often in Akkadian incantation literature to assist the troubled patient. There are several other occasions where the daughters of Anu appear in incantations, especially in the context of mannam lušpur-formula studied by Farber (1990; 1998, 64 f $)^{10}$, where it is however implied, although not expressly stated, that they descend from heaven. The fact that the mārāt Ani(m) are known to come down from heaven is directly declared in the historiola known to Assyriologists as The Cow of Sîn, (§§ 3.1.1.1-3.1.1.4). Although it is usually clear that the daughters of Anu come to the aid of the patient, we find, in the continuation of $\S$ 3.1.2.1, a verbal explanation about their descent, i.e.:

\subsubsection{Maqlû-series III 34-39 (spell against witchcraft)}

Recent Edition: Abusch 2016, 304 f

ēkīam tebâtina ēkīam tallakā

ana èpiši u êpišti ša annanna mār

annanna ana sahāiri nillika

ana luqquti ša hușābišina

ana ḩummumi ša ḩumāmātišina

ša līlâti huluppaqqa ana šarāpi nillika

\begin{abstract}
"For what have you risen? Where do you go?”

- We have come to seek out the sorcerer and sorceress of So-and-So, the son of So-and-So.

In order to collect their leavings, In order to gather their refuse, In order to light the brazier at night we have come! -
\end{abstract}

Besides the kindly daughters of Anu, we find benevolent materia magica, such as tin and zalāqu-stone coming down (§ 3.1.1.5). Like the diseases, these materia magica are also personified and appear to act autonomously: it is vividly described that these daughters carry dispelling rituals on their heads.

10 For further discussion of the daughters of Anu in a hyleme-sequence of the Late-Hellenistic incantation "Philinna Papyrus" on mystodokos and the dark-eyed maidens, see Faraone 1995. 
3.1.2 " $\mathrm{X}_{2}$ (=Benevolent) Descends from Heaven" - No Specified Instrument

\subsubsection{1 (MB/MA) AS 16, $287 \mathrm{f}$ ( $R \mathrm{~m}$ 376): ii 30 (spell aiding childbirth)}

Recent Edition: Veldhuis 1991, 10 f; Rowe 2015, 54 f

2-ta ${ }^{\mathrm{d}}$ LAMMA AN-e $u_{2}-r i-d a-n i$

Two lamassus (i.e., tutelary dei-

ties) of heaven descended

3.1.2.2 (MB/MA) AuOr Suppl. 23, 20 (RS 24.436): 3' (spell aiding childbirth) Recent Edition: Arnaud 2007, 75-77; Rowe 2014, 77 f; 2015, 54 f

2 la-mas-sa-at [AN-e u2-ri-da-ni-(ma)] Two lamassus (i.e., tutelary deities) of [heaven descended]

3.1.2.3 (MB/MA) Iraq 31, pl. $\mathrm{V} \mathrm{f}$ (Private Collection): r. 59 (spell aiding childbirth)

Recent Edition: Rowe 2015, 54 f; Zomer 2018, 254-256

2 ši-na DUMU.MUNUS ${ }^{\mathrm{d}} A$-nim TA AN-e Two are the daughters of Anu, $u_{2}-r i-d a-a-n i$ they descended from heaven

3.1.2.4 (SB) BAM 248 (VAT 8869): iii 25 // AMT 67/1 (K 2413+): iii 19 (spell aiding childbirth)

Recent Edition: Veldhuis 1991, 8 f.61-63; Rowe 2015, 54 f

2 d LAMMA.MEŠ AN-e $u_{2}$-ri-da-nimz-ma Two lamassus (i.e., tutelary deities) of heaven descended

3.1.2.5 (SB) SpTU 4, 140 (W 22577/1): r. 15’ // AMD 8/1, pl. 44 f (BM 38635): 9' $f$ (spell against witchcraft)

Recent Edition: Abusch/Schwemer 2011, 159-199 


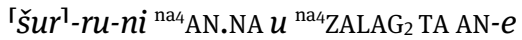
ur-du-ni [ina? ${ }^{[}{ }^{\mathrm{SAAG}}{ }^{?}{ }^{?}-\check{S}_{2}-n u$ na-šu- $u_{2}$ piš- ${ }^{\mathrm{T}} r e^{\mathrm{T}}-e^{-}{ }^{\mathrm{T}} t \mathrm{u}_{4}{ }^{\mathrm{T}}$
Descending, tin ${ }^{11}$ and zalāqu-stone came down from heaven! [On] their heads they carry dispelling rituals!

\subsection{3 “ $\mathrm{X}_{2}$ (=Benevolent) Descends from Heaven" - with țurru "String"}

\subsubsection{1 (SB) Maqlû-series III 31-33 (spell against witchcraft)}

Recent Edition: Abusch 2016, 83 f.304 f

2-ta šina DUMU.MUNUS.MEŠ ${ }^{\mathrm{d}} A$-nim ša $a_{2}$ AN-e 3-ta ši-na DUMU.MUNUS.MEŠ ${ }^{\mathrm{d}} A$-nim ša $a_{2}$ AN-e țur-ra (var. -ri) șab-ta-nim-ma ultu AN-e ur-ra-da-ni
Two are the daughters of Anu of heaven(s); three are the daughters of Anu of heaven(s); they grasped a string and are descending from heaven

\section{Variant: " $X_{(1-2)}$ Makes $Y_{(1-2)}$ Descend from Heaven"}

\section{1 " $X_{1}\left(=\right.$ Malevolent) Makes $Y_{1}(=$ Malevolent $)$ Descend from Heaven"}

Only one possible example (§ 4.1.1.1) can be presented where the hyleme-subject $\left(\mathrm{X}_{1}\right)$ is a malevolent entity forcing another malevolent entity - here the hylemeobject $\left(\mathrm{Y}_{1}\right)$ - to descend from heaven. It should be noted that the restoration, in this example, of the predicate $\left(u_{2}-\left[\check{s}_{2}{ }_{2}{ }^{2}-r i^{?}\right]-d u\right)$ as a causative $(w) \operatorname{ara\overline {d}}(u$ (S) "to make s.o. descend" is uncertain and a form $\left(u_{2}-\left[r^{?}\right]-d u\right)$ of $(w) \operatorname{ara} d u(G)$ cannot be excluded. Advocating the former possibility is the allusion to witchcraft found in a Neo-Assyrian letter (SAA 16, 63: r. 26'): '30 TA AN-e $u_{2}$-še-ra-da-a-ni "they (i.e., the women of Gūzāna) let the moon descend from heaven". ${ }^{12}$ In both cases, malevolent human agents (i.e., sorcerers) are capable of manipulating objects to cause their descent from heaven.

11 Transliteration follows here $S p T U$ 4, 140, whereas $A M D$ 8/1, pl. $44 \mathrm{f}$ reads NA4 ${ }^{\mathrm{d}} A-n u$ "stone of Anu". See Abusch/Schwemer 2011, 196.

12 See Reiner 1995, 98; Schwemer 2007, 104 f. 


\subsubsection{Overview Attestation " $\mathrm{X}_{1}$ (=Malevolent) Makes $\mathrm{Y}_{1}(=$ Malevolent) Descend from Heaven”}

\subsubsection{1 (SB) PBS 10/2, 18 (CBS 1203): 39’ // AMD 8/1, pl. $54-58$ (K 3360+): 9' (spell against witchcraft)}

Recent Edition: Abusch/Schwemer 2011, 270-292

[șalmīya īpušū-ma ištu/itti?] MUL

$\check{s} a_{2}-m a-m i \quad u_{2}-\left[\check{s}_{2}{ }_{2}-r i^{?}\right]-d u$
[They (i.e., sorcerers) have made (bewitched) figurines of me and from/with] a star of heaven they let it come down

The restoration [șalmìya ìpušu-ma "they have made (bewitched) figurines of me"] follows the enumeration within the incantation itself. Whereas Abusch/Schwemer $(2011,285)$ interpret thereafter $\mathrm{GIN}_{7} /$ kima to mean "like", a restoration of $\mathrm{TA} / i \check{s} t u$ "from" or $\mathrm{KI} / i t t i$ "with" seems more plausible in light of the evidence presented in $\S 2.2 .4$.

\section{2 “ $\mathrm{X}_{2}$ (=Benevolent) Makes $\mathrm{Y}_{1}(=$ Malevolent) Descend from Heaven"}

The most notorious, malevolent daughter of Anu is the demoness Lamaštu. With her horrific nature, ${ }^{13}$ she assumes an exceptional position regarding the hyleme-pattern " $\mathrm{X}_{(1-2)}$ descends from heaven", since she was purportedly expelled from heaven. The terminology used to describe her banishment is the verb napāșu "to smash down" in the second millennium (§§ 4.2.1.1-4.2.1.2), but for the later series the causative ( $\breve{S})$ of (w)arādu "to make s.o. descend" is used $(\S 4.2 .1 .3)$.

\subsubsection{Overview Attestations of " $X_{2}\left(=\right.$ Benevolent) Makes $Y_{1}(=$ Malevolent) Descend from Heaven"}

\subsubsection{1 (OA) BIN 4, 126 (NBC 3672): 10-13 (spell against Lamaštu)}

Recent Edition: Farber 2014, 259

13 For a discussion on Lamaštu's nature, see Farber 2007. 
A-nu-um a-bu-ša iš-tü ša-ma-e $i-p u$-șa-ši $q a_{2}-q a_{2}-a r-s ̌ u-u m$
Anum, her father, cast her down from heaven to earth

\subsubsection{2 (MB/MA) AS 16, $287 \mathrm{f}$ ( $\mathrm{Rm}$ 376): iv 21-23 (spell against Lamaštu?)}

Recent Edition: Lambert 1965, 283-288; Zomer 2018, 328-330

DINGIR.MEŠ GAL.MEŠ ${ }^{\mathrm{d}} \mathrm{XXX} u{ }^{\mathrm{d}} \mathrm{U} . G U R$

$e-t i_{2}-r u-t u{ }^{\mathrm{d}} E_{2}-a$ EN TU ${ }_{6}{ }^{\mathrm{d}}\left[\mathrm{ASAL} . \mathrm{LU}_{2}\right.$.HI $]$ EN

ne $-m e-q i{ }^{\mathrm{d}} \mathrm{Gu}-\mathrm{la}$

$a$-su-gal-la-at DINGIR.MEŠ GAL.[MEŠ ...]

i-ta-ap-șu $u^{14} i$-na pa-ni AN-e ša

dA-nim
The great gods Sîn and Nergal, the saviours, Ea, the lord of the incantation, [Asalluhi] the lord of wisdom, Gula, the chief physician, the great $\operatorname{god}[s . .$.$] have cast her out of heaven,$ the heaven of Anu

It remains uncertain whether the incantation cited in $\S$ 4.2.1.2 is intended against the demoness Lamaštu. It concerns a great evil feminine power, afflicting various tiers of society, but its name is not preserved. Reasons to believe Lamaštu may be involved here is the rather unique occasion of an evil entity being cast out of heaven - which is otherwise only known from the Old Assyrian Lamaštu incantation $\S 4$.2.1.1 - the reference to an insatiable pig and the phrase la banita "the not good one". Other possible candidates are "the evil eye" or "the witch".

\subsubsection{3 (SB) Lamaštu-series I $111 \mathrm{f}$ (spell against Lamaštu)}

Recent Edition: Farber 2014, 83

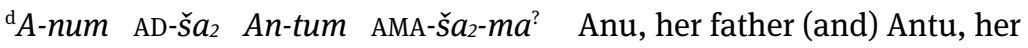
ina ep-še-ti-ša ${ }_{2}$ la ba-na-ti iš-tu AN-e mother who, because of her unseem-

$u_{2}$-še-ri-du-niš-šim-ma ly deeds, made her descend from heaven

14 Pace Lambert 1965, I suggest reading i-ta-ap-șu (ittapșū) instead of i-ta-ap-rik $k_{2}$ (ittaprik), preferring the common phonetic value /șu/ over / $/ \mathrm{rik}_{2} /$, see Zomer 2018, 330. 


\section{Variant: " $\mathrm{X}_{1}(=$ Malevolent $)$ Descends from the Mountainous Regions"}

The image of Lamaštu's exile from heaven, as described in §§ 4.2.1.1-4.2.1.3, encourages us to consider the possibility of a new point of origin. This has resulted in the case of Lamaštu in a new variant of the studied hyleme-pattern, i.e., " $\mathrm{X}_{1}$ (=malevolent) descends from the mountainous regions", shifting the hyleme-source "heaven" to the uninhabited "mountainous region". The arrival of evil entities from such places derives from an older Sumerian tradition, where kur may denote mountain, but is simultaneously the ordinary term for the Netherworld..$^{15}$ The logogram KUR is the equivalent of Akkadian šadû "mountains" and mātu "land". The oldest attestation of this variant is found in a Sumerian incantation (§ 5.1.6) against the Samana-disease dating from the Old Akkadian period. The same image is repeated over a thousand years later in an incantation against the same disease ( $§$ 5.1.5). It appears that, in both spells, the disease derives from the mountainous regions and not from the Netherworld per $s e$. As for the examples concerning Lamaštu (§§ 5.1.1-5.1.4), the imagery used to dispel her affirms the mountains to be part of the uninhabited wilderness. ${ }^{16}$

\subsection{Overview Attestations of Variant: " $X_{1}$ Descends from the Mountainous Regions"}

\subsection{1 (MB/MA) MC 17, 443 f (BM 120022): 13 (spell against Lamaštu)}

Recent Edition: Farber 2014, 120-125

ul-tu $u_{4}$ kul-la-at ša-di-i ra-bu- $u_{2}$-tim $\quad$ From all the great mountains, she $u_{2}$-ri-da-am-ma (i.e., Lamaštu) descended

\subsection{2 (SB) Lamaštu-series II 35 (spell against Lamaštu)}

Recent Edition: Farber 2014, 100

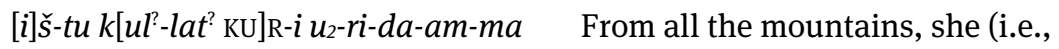
Lamaštu) descended

15 Horowitz 1998, 272 f.

16 Farber 2014, 3.249.251. 


\subsection{3 (SB) Lamaštu-series II 163 (spell against Lamaštu)}

Recent Edition: Farber 2014, 121

iš-tu kul-lat kur-i u $u_{2}$-ri-dam-ma

From all the mountains, she (i.e., Lamaštu) descended

\subsection{4 (SB) Ludlul bēl nēmeqi II 55}

Recent Edition: Oshima 2014, $88 \mathrm{f}$

la-maš-tu $u[r]-d a$ ul-tu qe 2 -reb KUR-i

Lamaštu descended from the midst of the mountains

\subsection{5 (SB) STT 178 (Su.51/128+129+233): 15-18 // AMT 61, 7: r. 1'-4' (spell against Samana)}

Recent Edition: Finkel 1998, 87-92

kur-ta〈k̂en〉-na-ta kur-〈ta〉

gen-na-[ta]

iš-te ša $a_{2}$ de-e il-la-ku iš-te š $a_{2}-[d e]-{ }^{-} e^{1}$ $u r-d a$

[n] im-nim kur-ta ĝen-na-ta

Sa-ma-nu iš-tu šaz-de-e ur-da
Sum: Coming from the mountain, coming from the mountain!

Akk: Coming down from the mountains, it came down from the mountains!

Sum: Samana coming from the mountain!

Akk: Samana came down from the mountains!

\subsection{6 (OAkk.) CM 10, 76 f (6 NT 145): 1-7}

Recent Edition: Finkel 1998, 76 f

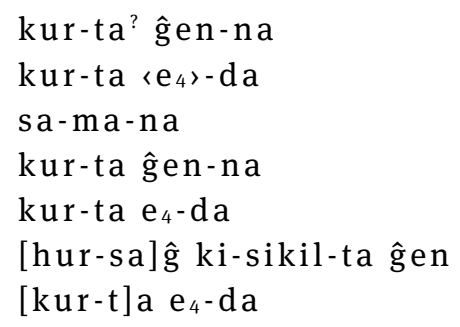

Coming from the mountain!

«Coming down〉 from the mountain!

Samana!

Coming from the mountain!

Coming down from the mountain!

Coming from the pure mountain!

Coming down from the mountain! 
Pace Finkel (1998, 76 f), read /e 4 / (A) and not /e $/$ (NIN). We have here a phonetic rendering of Sumerian / $\mathrm{e}_{11} . \mathrm{d} /$ "to descend/ascend".

\section{Evaluation Hyleme-Pattern " $\mathrm{X}_{(1-2)}$ Descends from Heaven"}

\subsection{Hyleme-Subject $\mathrm{X}_{(1-2)}$}

The interesting innovation within Akkadian incantations starting from the second millennium is the fact that evil entities are occasionally now described as autonomously coming down from heaven, apparently acting on their own initiative, making the grammatical subject identical with the hyleme subject. ${ }^{17}$ Frequently, it is stated that hyleme-subject $\mathrm{X}_{1}$ (=malevolent) comes down from heaven independently, i.e., the apīatu-disease, fever (išātu "fire"), the maškadudisease (brucellosis? ${ }^{18}$ ), māmìtu (malevolent oath), collapse (miqittu) and Lamaštu exclusively in the variant " $\mathrm{X}_{1}$ (=malevolent) descends from the mountainous regions". On the other hand, there is the imagery of groups of diseases collectively descending from heaven (§§ 2.2.1.3-2.2.1.5; 2.2.1.7; 2.2.1.13; 2.2.3.2.1; 2.2.4.1; 2.2.4.6). Wasserman (2007) observed, for the Old Babylonian examples, that there is a correlation between these enumerations of diseases acting here as hyleme-subject $\mathrm{X}_{1}$ and their occurrence in therapeutic and lexical lists, indicating that they are by no means random or erratic. From the diseases descending individually, only fever (išātu) and a form of collapse, miqtu instead of miqittu, are attested in the skeleton-list extracted by Wasserman $(2007,45)$. Whereas the

17 It should, however, be noted that from the perspective of the ancient Mesopotamians, evil entities could be sent by higher authorities, (i.e., deities), e.g., the famous passage in Atrahasiss, the Babylonian flood story, where Enlil addresses the other deities with a speech outlining his plan to afflict mankind (SB) (K 3399+3934): iv 9-12: [qi-b]a-ma šu-ru-pu-u lib-ši, [li-š]ak-li-ṣi rigim-ši-na nam-tar, [ki-m]a me-he-e li-zi-qa-ši-na-ti-ma, [mur]-șu di-’u šu-ru-pu-u a-sa-ku "Command that there will be a chill! Let Namtar diminish their noise! Like a tempest let blow upon them: sickness, di'u-disease, shivering, (and) the asakku-disease!” In the present case study, it is not explicitly stated - and it can therefore not automatically be assumed - that the evil entities are here released by divine authority. Note that, if we were to implicitly assume the discharge of evil entities by a divine being, in hyleme-theory, the grammatical subject in the hyleme-pattern " $\mathrm{X}_{(1-2)}$ descends from heaven" would in fact be the hyleme object and the studied hyleme-pattern would actually be "[ $\mathrm{X}_{(1-2)}$ makes $] \mathrm{Y}_{(1-2)}$ descend from heaven".

18 For the possible identification of the maškadu-disease with brucellosis, see Wasserman 2012. 
enumerations of diseases in the present hyleme-pattern are concerned with the question of the aetiology of diseases, Wasserman (2007, 44) identified another sub-group of enumerations within Akkadian incantations without the discussed hyleme-pattern. Here the maladies are depicted to be ever-present and to accompany demonic powers. In this respect, we should note the Middle Babylonian example (§ 2.2.1.6), left undiscussed by Wasserman, where we find a synthesis of both the diseases and demonic powers descending from heaven, as detailed in the table below.

Tab. 1: Diseases and Demonic Powers Descending from Heaven According to § 2.2.1.6

\begin{tabular}{|c|c|}
\hline ašû & a disease affecting the head \\
\hline samana & fungal skin infection (?) \\
\hline amurriqānu & jaundice \\
\hline$a h h \underline{a} z u$ & jaundice caused by the a-demon \\
\hline ummu & fever \\
\hline li'bu & fever \\
\hline almu & the almu-demon \\
\hline allamu & the allamu-demon \\
\hline diu & a disease affecting the head \\
\hline alû & a demon \\
\hline kuraštimmu & kind of eczema \\
\hline ummu & fever \\
\hline naplaštu & the blinker-demon \\
\hline utukku & the utukku-demon \\
\hline šīqu & kind of eczema \\
\hline šaššațu & a disease of the joints \\
\hline [lamaštu] & [the lamaštu-demoness] \\
\hline labāṣu'(text: ahhāzu) & the labāṣu-demon \\
\hline ahhhāzu & the ahhāzu-demon \\
\hline hayyattu & the hayyattu-demon \\
\hline lilû & the lilû-demon \\
\hline lilītu & the lilitu-demon \\
\hline ardat lilî & the ardat-lilî-demon \\
\hline$n e ́-r a \sim\left\ulcorner a p^{\top}-p i_{2}\right.$ & the striking-of-the-nose affliction \\
\hline ḩimiț-șeêti & sunstroke \\
\hline gallû & the gallû-demon \\
\hline
\end{tabular}


As for the hyleme-subject $\mathrm{X}_{2}$ (=benevolent) in the hyleme-pattern " $\mathrm{X}_{(1-2)}$ descends from heaven", this role is mainly attributed to the benevolent daughters of Anu, sometimes specified as lamassāt šamê "the lamassus (tutelary deities) of heaven", in the context of birth incantations. Whereas their corrupted counterparts the malevolent daughters of Anu, (e.g., māmitu "malevolent oath", Lamaštu) are said to descend singularly, the benevolent daughters generally descend as a pair. ${ }^{19}$ Another example of $\mathrm{X}_{2}$ (=benevolent) is found in $\S$ 3.1.1.5, where apparent inanimate ritual objects, i.e., tin and zalāqu-stone, are now the hyleme-subject.

The hyleme-subject $\mathrm{X}_{1}$ (=malevolent) in the variant " $\mathrm{X}_{(1-2)}$ makes $\mathrm{Y}_{(1-2)}$ descend from heaven" is only found in the case of witchcraft (§ 4.1.1.1), where sorcerers are said to have manipulated bewitched figurines $\left(\mathrm{Y}_{1}\right)$ to come down from heaven.

In the same variant, the hyleme-subject $\mathrm{X}_{2}$ (=benevolent) is apparently limited to the banishment of the demoness Lamaštu (= hyleme-object $\left.Y_{1}\right)$. In the earliest Old Assyrian example, $\mathrm{X}_{2}=\mathrm{Anu}$, her father (§4.2.1.1); in a later example, dating from the Middle Assyrian period, we find an enumeration of gods, $\mathrm{X}_{2}=$ Sîn, Nergal, Ea, Asalluhi, Gula, ... (§ 4.2.1.2) and the Lamaštu-series of the first millennium simply states $\mathrm{X}_{2}=\mathrm{Anu}$, her father, Antu, her mother (§ 4.2.1.3).

Interestingly, the hyleme-subject $X_{1-2}$ is frequently said to be related to $\mathrm{An}(\mathrm{u})$, the Mesopotamian god of heaven, i.e., märat Ani $(\mathrm{m})$ "Daughter of Anu" and is always female; we never find $\operatorname{ma} r \operatorname{Ani}(m)$ "son of Anu". These daughters can be divided in two groups, i.e., the benevolent daughters acting as tutelary deities to troublesome patients in pain and the malevolent daughters attacking the patient. Despite being each other's exact counterpart, they never appear simultaneously within an incantation and can never switch sides. As for the male offspring of Anu in Mesopotamian incantations, we should note the occurrence of the evil Utukku-demons, who are said, in the Udug.hul-series, to be "the seed of Anu" (a-an-na a-ri-a-me-eš // ša rihût Anim rehûu).

\subsection{Hyleme-Object $Y_{(1-2)}$}

Examples of a hyleme-object $\left(\mathrm{Y}_{1-2}\right)$ can only be found in the variant: " $\mathrm{X}_{(1-2)}$ makes $\mathrm{Y}_{(1-2)}$ descend from heaven". Examples for $\mathrm{Y}_{1}(=$ malevolent) are attested for (be-

19 It should, however, be noted that the witches in $\S$ 2.2.1.8 are most likely to be identified as malevolent daughters of Anu, since their actions (carrying water from the ocean) are identical to those of the benevolent daughters. Note additionally that witches are referred to as Daughters of Anu in the anti-witchcraft series Maqlû III 63; VI 87. 
witched) figurines (of the victim) (§ 4.1.1.1) and the demoness Lamaštu (§§ 4.2.1.1-4.2.1.3). We find only one example of $\mathrm{Y}_{2}$ (=benevolent) in $\S 3.1 .1 .5$, where "dispelling rituals” (pišrētu) are carried down from heaven.

\subsection{Hyleme-Predicate}

The Akkadian verb (w)arādu (G) "to descend, to go down" is mainly used for the hyleme-predicate. In the few instances where we have a Sumerian version, we find the corresponding verb / $\mathrm{e}_{11} . \mathrm{d} /(\S \S 2.2 .1 .1 ; 2.2 .1 .12)$. For the variant " $\mathrm{X}_{1-2}$ makes $\mathrm{Y}_{1-2}$ descend from heaven", we find the causative (w)arādu (̌́) "to make s.o. descend, to go down” (§§ 4.1.1.1; 4.2.1.3). Other verbs used are maqātu (G) "to fall (down)" (§ 2.2.5.1), here a play with the inherent meaning of the hylemesubject RI.RI.GA/miqittu “collapse” and napāṣu (G) "to smash (down)”, which is exclusively used in the second millennium ( $\S \S 4.2 .1 .1-4.2 .1 .2)$ to express the banishment of the demoness Lamaštu from heaven in the variant " $\mathrm{X}_{2}$ (=benevolent) makes $\mathrm{Y}_{1}(=$ malevolent $)$ descend from heaven". The vast majority of hylemepredicates are consistently found in the past tense, i.e., preterite and - to a lesser extent - in the perfect tense; only once do we find the use of the present tense (§3.1.2.1). This preference for the past tense can simply be explained by the fact that the studied hyleme-pattern and its variants are found in historiolae/hyleme-sequences in introductions to incantations alluding to a mythical antecedent.

\subsection{Hyleme-Instrument}

\subsection{1 țurru "String”- șerretu “(Leading-)Rope"/șertu “Udder”}

There is no consensus as to whether șerretu "(leading-)rope" or șertu "udder" is used in our context and indeed it is difficult to see the difference in the construct state. ${ }^{20}$ However, the evidence from the Middle Babylonian and Middle Assyrian periods of the parallel use of țurru has thus far been neglected. Observing the almost identical use of țurru in the same context, I would like to argue for șerretu instead of șertu in this hyleme-pattern within Akkadian incantations.

20 Udder: Farber 1990, 307 (more poetic 'Milky Way'); Stol 1993, 13; Wasserman 2007, 44 n. 3. (Leading-)rope: Collins 1999, 335. 
The vivid expression "it grasped the (leading-)rope, it descended from heaven" ișbat țurra ištu šamê urda $(m)$ or "from the rope of heaven, it descended" ištu șerret šamê urda $(m)$ brings to mind the famous Jacob's ladder described in Genesis 28: 10-19, where it is said that, in Jacob's dream, a ladder is set on the earth reaching towards heaven to enable the angels of God to ascend and descend between both realms. As can be observed from other examples containing the hyleme-pattern under discussion, such as $\S \S 3.1 .1 .1-3.1 .1 .5$ and $\S 3.1 .2 .1$, journeying between heaven and earth within Mesopotamian incantation literature is a device employed by benevolent entities, such as the use of ritual stones by the benevolent daughters of Anu; however, contrary to Jacob's ladder, the rope in the hyleme-pattern " $\mathrm{X}_{(1-2)}$ descends from heaven" appears to permit only a singular direction of travel, i.e., heaven $\rightarrow$ earth. Numerous texts refer to cosmic bonds which secure the heavens in place (see Horowitz 1998, 265). These ropes existed in the imaginations of everyday Mesopotamians and were key to their conceptualization of the world.

\subsection{2 kakkabu "(Falling) Star"}

The image of a falling star as an instrument for transferring diseases/demons from heaven to earth speaks easily to the imagination. As Wasserman $(2007,46)$ contends, one might argue that falling stars could start fires upon impact, appealing to the Mesopotamian belief that diseases spread simultaneously with their appearance. Note, however, that fever, which is called literally "fire" (IZI/išâtu), is always reported - in the studied hyleme-patterns - to descend to earth by rope, see $\S \S 2.2 .2 .1-2.2 .2 .2$. Interestingly two prepositions are used for "the star(s) of heaven", KI/itti "with" (§§ 2.2.4.2-2.2.4.3) and TA/ištu "from" ( $\S \S$ 2.2.4.1; 2.2.4.4-2.2.4.6). ${ }^{21}$ Although the former technically denotes the star(s) as an instrument and the latter as a point of origin, both seem to appeal to image of falling stars. Falling stars were a common event in ancient times and it can be supposed that the idea that stars could be a vehicle for transporting maladies

21 Another possible example may be found in the fragmentary OB incantation YOS 11, 9: 1-3 sí-ka-tum i-ša-tum mi-iq-tum bé-[nu-um] šu-ru-up-pu-ú-um ù sa-ma-nu-[um] iš̀-tu ${ }_{4}$ kakka$\operatorname{bim}(\mathrm{MUL})\left\{\mathrm{x}^{?}\right\}$ ur-da. 
can be interpreted literally, i.e., natural phenomena were believed to instigate diseases. $^{22}$

\subsection{Hyleme-Source}

The geographical point of origin in the hyleme-pattern under study is, of course, heaven: often this is described in general terms as ištu šamê "from heaven", but on some occasions the exact geographical point of origin in heaven is described with greater specificity.

\subsection{1 ziqqurat šamê "Temple Tower of Heaven"/zuq(q)urān šamê "Height of Heaven"}

It should be noted that both attestations $\S \S$ 2.2.1.4-2.2.1.5 are hapax legomena and hence are poorly understood. ${ }^{23}$ However, there is one attestation known from the Gilgameš epic that could shed some new light on this matter:

\section{(SB) Gilgameš XI 158}

Recent Edition: George 2003, $712 \mathrm{f}$

ašz-kun sur-qin-nu ina UGU ziq-qur-rat I (i.e., Ūta-napišti) strewed incense on KUR the ziqqurat of the mountain

ziqqurat is used here in a transferred meaning, i.e., to be translated as "peak of the mountain". ${ }^{24}$ From this viewpoint, ziqqurat in $\S 2.2 .1 .4$ can be interpreted the same way, i.e., "the peak of heaven". The substantive $z u q(q) u r \bar{n} n$ to be derived from the same root as ziqqurat, i.e., $v z q r$ "to build high" (D) "to raise, build high" with the suffix - ān- is likely to be translated as "height". ${ }^{25}$ In this respect, we should note the OB unilingual Sumerian incantation $\S$ 2.2.1.1, where the

22 For consideration of the fact that falling stars were generally considered to be a negative omen in Mesopotamia, see Oppenheim 1956, $283 \mathrm{f}$. For discussion of namburbi-rituals against the evil of falling stars, see Maul 1994, 453-457.

23 Cavigneaux 1994, 159, pace Farber 1990, 307 n. 48 does not accept the hapax legomenon for $\S$ 2.2.1.4 and prefers to relate it to $\sqrt{ } s k r$, translating it to mean "the closed off regions of heaven".

24 George 2003, 713 n. 37.

25 Cavigneaux 1994, 159. 
celestial point of origin is "height of heaven" (sa $\hat{\mathrm{g}}$ a n-ta). It seems plausible that § 2.2.1.1 and § 2.2.1.5 refer to the same geographical origin in heaven. For a discussion on the zenith of heaven and other designations thereof, see Horowitz (1998, 236-238).

\subsection{2 qereb šamê "the Midst of Heaven"}

The notion qereb šamê "the midst of heaven" (§ 2.2.1.12) occurs once. It is noteworthy that, in the variant " $\mathrm{X}_{1}(=$ malevolent $)$ descends from the mountainous regions", its counterpart occurs qereb šadê "the midst of the mountains" (§ 5.1.4) and in the Sumerian hyleme-pattern " $\mathrm{X}_{(1-2)}$ came out the Abzu" we find in the example from Šurpu cited above - ša $\mathrm{a}_{3} \mathrm{abzu}$ - ta / qereb Apsî "the midst of the Abzu". For a discussion on the "midst of heaven" as a geographical location, see Horowitz (1998, 238 f).

\subsection{3 ina pāni šamê "in Front of Heaven"}

The Middle Assyrian incantation, presumably against Lamaštu cited in $\S$ 4.2.1.2, uses the expression ina pāni šamê ša Anim. For a discussion on pāni šamê lit. "the face of heaven" as a geographical location in heaven, see Horowitz (1998, 241). Pace Horowitz's $(1998,246)$ translation "on the face of heaven"; for the present attestation, however, a better translation of the prepositional phrase ina $p \bar{a} n i$ "in front of" seems more warranted. Furthermore, it is specified that it is in front of heaven that the female evil entity is dispelled, i.e., šamê ša Anim "the heavens of Anu", which is interpreted by Horowitz $(1998,244-246)$ to be the highest level of heaven, but could - on the other hand - very well be a general epithet for the totality of heaven.

\subsection{Hyleme-Goal}

The silent goal of the hyleme-pattern " $\mathrm{X}_{(1-2)}$ descends from heaven" and its variants is of course earth, i.e., the inhabited world, since it occurs within historiolae/(mythical) hyleme-sequences within incantations explaining the origin of evil and its occurrence in human society.

Only twice it is explicitly stated, i.e., ina qaqqari /qaqqaršum "on the ground (i.e., earth)" (§§ 2.2.5.1; 4.2.1.1). Another implicit way of denoting the hyleme-goal is the use of the ventive $-a(m),-n i(m),-m$ in Akkadian affixed to 
the hyleme-predicate. The function of the Akkadian ventive is that of an "allative" denoting a motion toward an intended goal. In the discussed hylemepattern and its variants, the hyleme-source is always given, i.e., heaven or a specific region thereof. Therefore, the intended goal conveyed with the ventive in the hyleme-predicate, generally expressed with (w)arādu (G) "to descend, come down", must be earth, i.e., the inhabited world, to be inferred by the audience. As for the variant " $\mathrm{X}_{1}$ (=malevolent) descends from the mountainous region", the hyleme-source is the uninhabited mountainous region, the intended goal of descent by the evil entity - expressed by the ventive in the hylemepredicate - is now not per definition the earth as opposed to heaven, but rather the inhabited world in contrast to the uninhabited world. The ventive is consistently found in the hyleme-predicate, except for $\S \S 2.2 .3 .3$; 4.2.1.2.

\section{Bibliography}

Abusch, T./Schwemer, D., 2011, Corpus of Mesopotamian Anti-Witchcraft Rituals, Ancient Magic and Divination 8.1, Leiden.

Arnaud, D., 2007, Corpus des Textes de Bibliothèque de Ras Shamra-Ougarit, Aula Orientalis Supplementa 23, Barcelona.

Böck, B., 2007, Das Handbuch Muššu’u ,Einreibung‘. Eine Serie sumerischer und akkadischer Beschwörungen aus dem 1. Jt. vor Chr., Biblioteca del Próximo Oriente Antiguo 3, Madrid. Cavigneaux, A., 1994, Magica Mariana, in: Revue d’Assyriologie et d'Archéologie Orientale 88, 155-161.

Collins, T. J., 1999, Natural Illness in Babylonian Medical Incantations, PhD-Diss., University of Chicago, Ann Arbor.

Conti, G., 1997, Incantation de l'eau bénite et de l'encensoir et textes connexes, in: Mari. Annales de Recherches Interdisciplinaires 8, 253-272.

Cunningham, G., 1997, 'Deliver me from evil'. Mesopotamian incantations 2500-1500 BC., Studia Pohl Series Maior 17, Rome.

Dietrich, M., 1988, Marduk in Ugarit, in: Studi Epigrafici e Linguistici 5, 79-101.

Faraone, C.A., 1995, The Mystodokos and the Dark-Eyed Maidens: Multicultural Influences on a Late-Hellenistic Incantation, in: M. Meyer/P. Mirecki (eds.), Ancient Magic and Ritual Power, Religions in the Graeco-Roman World 129, Leiden, 297-334.

Farber, W., 1989, Schlaf, Kindchen, Schlaf! Mesopotamische Baby-Beschwörungen und Rituale, Mesopotamian Civilizations 2, Winona Lake.

Farber, W., 1990, Mannam lušpur ana Enkidu: Some new thoughts about an old motif, in: Journal of Near Eastern Studies 49, 299-321.

Farber, W., 2007, Lamaštu-Agent of specific disease or a generic destroyer of health, in: Finkel, I. L./Geller. M. J. (eds.), Disease in Babylonia, Cuneiform Monographs 36, Leiden/Boston, 137-145. 
Farber, W., 2014, Lamaštu. An Edition of the Canonical Series of Lamaštu Incantations and Rituals and Related Texts from the Second and First Millennia B.C., Mesopotamian Civilizations 17 , Winona Lake.

Finkel, I. L., 1998, A Study in Scarlet: Incantations against Samana, in: Maul, S. M. (ed.), Festschrift für Rykle Borger zu seinem 65. Geburtstag am 24. Mai 1994. tikip santakki mala bašmu ..., Cuneiform Monographs 10, Groningen, 71-106.

Geller, M. J., 1985, Forerunners to Udug-Hul. Sumerian Exorcistic Incantations, Freiburger Altorientalische Studien 12, Stuttgart.

Geller, M. J., 2016, Healing Magic and Evil Demons. Canonical Udug-hul Incantations, with the assistance of Luděk Vacín, Die babylonisch-assyrische Medizin in Texten und Untersuchungen 8, Boston/Berlin.

George, A. R., 2003, The Babylonian Gilgamesh Epic. Introduction, Critical Edition and Cuneiform Texts, Oxford.

George, A. R., 2016, Mesopotamian Incantations and Related Text in the Schøyen Collection, Cornell University Studies in Assyriology and Sumerology 32, Bethesda.

Goetze, A., 1955, An Incantation against Diseases, Journal of Cuneiform Studies 9, 8-18.

Guichard, M. 2019, De Larsa à Mari (I): nouvelles incantations paléo-babyloniennes, in: Semitica 61, 5-14.

Heeßel, N., 2000, Babylonisch-assyrische Diagnostik, Alter Orient und Altes Testament 43, Münster.

Horowitz, W., 1998, Mesopotamian Cosmic Geography, Mesopotamian Civilizations 8, Winona Lake.

Katz, D., 2003, The Image of the Netherworld in Sumerian Sources, Bethesda.

Lambert, W. G., 1965, A Middle Assyrian Tablet of Incantations, in: Güterbock, H. G./Jacobsen, T. (eds.), Studies in Honor of Benno Landsberger on His Seventy-Fifth Birthday April 21, 1965, Assyriological Studies 16. Chicago, 283-288.

Lambert, W. G., 1969, A Middle Assyrian Medical Text, in: Iraq 31, 28-39.

Lambert, W. G., 1970, Fire Incantations, in: Archiv für Orientforschung 23, 39-45.

Linton, D., 1970, The Series SAG.GIG.GA.MEŠ and Related Incantations, MA-thesis, University of Birmingham.

Maul, S. M., 1994, Zukunftsbewältigung. Eine Untersuchung altorientalischen Denkens anhand der babylonisch-assyrischen Löserituale (Namburbi), Baghdader Forschungen 18, Mainz.

Nougayrol, J., 1968, Textes suméro-accadiens des archives et bibliothèques privées d'Ugarit, in: Nougayrol, J./Laroche, E./Virolleaud, C. (eds.), Nouveaux Textes Accadiens, Hourrites et Ugaritiques des Archives et Bibliothèques privées d'Ugarit. Commentaires des Textes Historiques, Ugaritica 5, Paris, 1-446.

Oppenheim, A. L., 1956, The Interpretation of Dreams in the Ancient Near East. With a Translation of an Assyrian Dream-Book, Philadelphia.

Oshima, T., 2014, Babylonian Poems of Pious Sufferers, Orientalische Religionen in der Antike 14, Tübingen.

Reiner, E., 1970, Šurpu. A Collection of Sumerian and Akkadian Incantations. Neudruck der Ausgabe 1958, Archiv für Orientforschung. Beiheft 11, Osnabrück.

Röllig, W., 1985, Der Mondgott und die Kuh. Ein Lehrstück zur Problematik der Textüberlieferung im Alten Orient, in: Orientalia. Nova Series 54, 260-273

Rowe, I. M., 2014, Babylonian Incantation Texts from Ugarit, in Del Olmo Lete, G., Incantations and Anti-Witchcraft Texts from Ugarit, with a contribution by Ignacio Márquez Rowe, Studies in Ancient Near Eastern Records 4, Boston/Berlin, 36-80. 
Rowe, I. M., 2015, Water of Labour? A Note on the Story of 'Sin and the Cow', in: Aula Orientalis $33,51-62$.

Rudik, N., 2015, Die Entwicklung der keilschriftlichen sumerischen Beschwörungsliteratur von den Anfängen bis zur Ur III-Zeit. Dissertation zur Erlangung des akademischen Grades Doctor philosophiae (Dr. phil.) vorgelegt dem Rat der Philosophischen Fakultät der Friedrich-Schiller-Universität Jena, https://www.dbthueringen.de/receive/dbt_mods_00026243.

Scurlock, J., 2014, Sourcebook for Ancient Mesopotamian Medicine, Writings from the Ancient World 36, Atlanta.

Schwemer, D., 2007, Abwehrzauber und Behexung. Studien zum Schadenzauberglauben im alten Mesopotamien, Wiesbaden.

Schwemer, D. see Abusch, T.

Stol, M., 1993, Epilepsy in Babylonia, Cuneiform Monographs 2, Groningen.

Tsukimoto, A., 1999, "By the Hand of Madi-Dagan, the Scribe and Apkallu-Priest" - A Medical Text from the Middle Euphrates Region, in: Watanabe, K. (ed.), Priests and Officials in the Ancient Near East, Papers of the Second Colloquium on the Ancient Near East - The City and its Life, held at the Middle Eastern Culture Center in Japan (Mitaka, Tokyo), March 2224, 1996, Heidelberg, 187-200.

van Dijk, J., 1969, Vert comme Tišpak, in: Orientalia. Nova Series 38, 539-547.

Veldhuis, N., 1991, A Cow of Sîn, Library of Oriental Texts 2, Groningen.

Wasserman, N., 2007, Between Magic and Medicine - Apropos of an Old Babylonian Therapeutic Text against kurārum disease, in: Finkel, I. L./Geller, M. J. (eds.), Disease in Babylonia, Cuneiform Monographs 36, Leiden/Boston, 40-61.

Wasserman, N., 2012, Maškadum and other zoonotic diseases in medical and literary Akkadian sources, in: Bibliotheca Orientalis 69, 426-436.

Wiggermann, F. A. M., 1996, Scenes from the Shadow Side, in: Vogelzang, M. E./Vanstiphout, H. L. J. (eds.), Mesopotamian Poetic Language: Sumerian and Akkadian, Cuneiform Monographs 6. Groningen, 207-230.

Zgoll, C., 2019, Tractatus mythologicus. Theorie und Methodik zur Erforschung von Mythen als Grundlegung einer allgemeinen, transmedialen und komparatistischen Stoffwissenschaft, Mythological Studies 1 (https://doi.org/10.1515/9783110541588), Berlin/Boston.

Zgoll, C., 2020, Myths as Polymorphous and Polystratic Erzählstoffe: A Theoretical and Methodological Foundation, in: Zgoll, A./ Zgoll, C. (Hg.), Mythische Sphärenwechsel. Methodisch neue Zugänge zu antiken Mythen in Orient und Okzident, Mythological Studies 2, Berlin/ Boston, 9-82.

Zomer, E., 2018, Corpus of Middle Babylonian and Middle Assyrian Incantations, Leipziger Altorientalistische Studien 9, Wiesbaden. 
